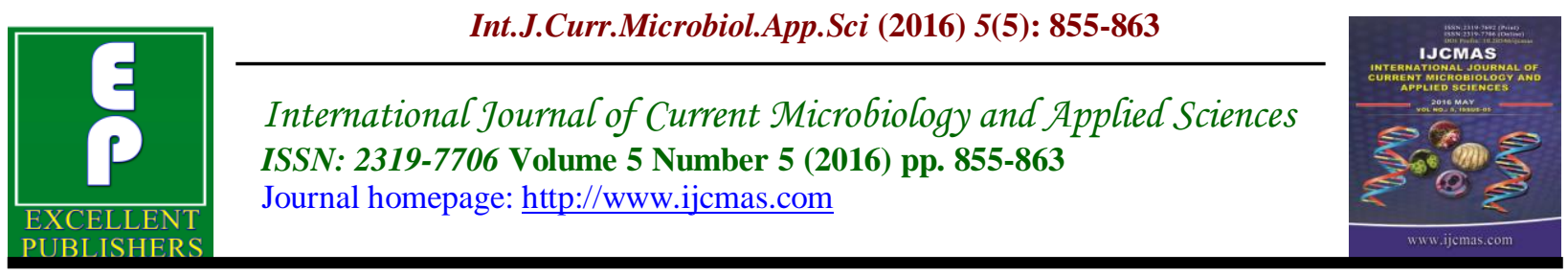

Case Study

http://dx.doi.org/10.20546/ijcmas.2016.505.088

\title{
A Case Study of Bovine Tuberculosis in Calf in Albania
}

\author{
Anita Koni ${ }^{1}$, Lenida Surraj ${ }^{2}$, Pëllumb Zalla ${ }^{1}$, Silva Tafaj $^{2}$ and Xhelil Koleci ${ }^{1 *}$ \\ ${ }^{1}$ Faculty of Veterinary Medicine, Agricultural University of Tirana, Albania \\ ${ }^{2}$ University Hospital, Shefqet Ndroqi, Tirana, Albania \\ *Corresponding author
}

\begin{tabular}{|c|c|}
\hline & A B S T R A C T \\
\hline \multicolumn{2}{|l|}{ Keywords } \\
\hline $\begin{array}{l}\text { Bovine } \\
\text { tuberculosis, } \\
\text { calf, } \\
\text { Albania. }\end{array}$ & \multirow{3}{*}{$\begin{array}{l}\text { Outbreak of bovine tuberculosis is rare reported in Albania. In this study we } \\
\text { confirmed the bTb diagnosis by using gross pathology examination, } \\
\text { microscopic examination of affected tissues, and Mycobacterium bovis } \\
\text { isolation and identification by culturing, colony morphology and Ziehl- } \\
\text { Neelsen stain. Typical mycobacteria were grown in both solid and liquid } \\
\text { media, however in liquid media M.bovis was grown faster than solid media. } \\
\text { In addition, isolates were typed by using spoligotyping method and M.bovis } \\
\text { was confirmed. }\end{array}$} \\
\hline Article Info & \\
\hline $\begin{array}{l}\text { Accepted: } \\
20 \text { April } 2016 \\
\text { Available Online: } \\
10 \text { May } 2016\end{array}$ & \\
\hline
\end{tabular}

\section{Introduction}

Bovine tuberculosis (bTB) is a contagious bacterial infectious disease that affects animals and humans (OIE, 2009). It occurs worldwide and it is a OIE listed disease and interfere seriously with international trade of animals and animal products (Nikki le Roex, et al., 2015). In general, bTB is a typical chronic disease. Humblet, et al., (2009) listed a long list of bTB risk factors and age was classified as an individual factor that affects clinical disease. Despite that animals may be infected at early age of life the clinical disease may appear when animals become older. In addition, older animals are more likely to be exposed to M.bovis. The main route of transmission of bTB is by inhalation; however congenital and suckling colostrum and milk from infected animals are described widely (OIE, 2009).
Diagnosis of bTB is an important factor that affects significantly the success of its control. Ante mortem diagnosis of bTB in cattle is based on tuberculin skin test (STs), Interferon Gama Assay (INF- $\gamma$ ), ELISA, Fluorescence Polarization Assay (FPA), etc. Sensitivity of diagnostic methods is low and both false positive and false negative affect their performance. Both STs and INF- $\gamma$ tests are based on cell mediated immunity, STs have low sensitivity and acceptable specificity, while INF- $\gamma$, despite the diagnostic parameters are better than STs, its specificity and sensitivity are still low.

However, using the tests in parallel is useful for detecting more infected animals than each test may be detecting (Gormley, et al, 2006). The serological methods such as 
ELISAs and FPA are available. The sensitivity is variable, while specificity of tests is acceptable. Skin tests may detect animals that are infected at list one month before performing the tests as this is the minimal time for late hypersensitivity status to be established (OIE, 2009).

The serological diagnosis based on specific antibodies to M.bovis is suitable for detecting the advanced cases of bTB. Young animals react less than adult animals in tests based in late hypersensitivity and serological test. Postmortem diagnosis is based on gross lesion characteristics, microscopic lesions, culturing and ZN staining (Norby, et al, 2004, Menin, et al., 2013).

Gross lesions are described as granulomatous inflammation; however, they are not specific for bTB, several other infections may develop the same morphology (Palmer MV et al, 2007). The microscopic examination reveals presence of caseous necrosis, epithelioid macrophages, lymphocytes, multinucleated giant cells and clusters of neutrophils. Culturing of M.bovis is a gold standard method for bTB diagnosis (Corner, et al., 1994; Ramakrishnan, 2012; Palmer, et al, 2007; Kumar, et al. 2013). It takes time, is expensive, requires biosafety level three laboratory, trained personnel etc. Characteristics of colonies and ZN staining are used for identification of M.bovis (OIE, 2009).

In order to type the isolated strain molecular methods may be used. Molecular typing has a particular importance for tracing back the cases and identifying the source of infection. In this study, we isolated, identified and typed the M.bovis from suspected tubercular gross lesions in a calf. The microscopic examination was performed in microscopic smears.

\section{Materials and Methods}

We used tissues and organs of abdominal cavity and lungs of a calf that were slaughter after a severe unspecified gastrointestinal signs.

\section{Gross Lesion Examination}

The examination of gross lesions was made by carefully examination of the organs admitted to laboratory of infectious disease at veterinary faculty, Tirana. The visual examination was combined with palpation and incision of the spleen, mesentery, liver, diaphragm and palpation and incision of mesenteric lymph nodes. The mesenteric lymph nodes, spleen and diaphragm were examined in details and were sectioned into $2 \mathrm{~cm}$ thick slices to facilitate the detection of visible lesions. The cut surfaces were examined under bright light for the presence of typical tubercular lesions such as: abscess, cheesy mass, and tubercles. The proper samples were selected and in parallel there were used for culturing and for histopathological examination.

\section{Histopathological Examination}

Histopathologic examination was based on tissue samples fixed in 10\% neutral buffered formalin and processed by standard paraffin wax techniques. Samples were cut and stained using the standard hematoxylineosin (H\&E) method. Slides were evaluated microscopically and classified as positive based on presence of tubercular granuloma displaying central necrosis with or without mineralization surrounded by macrophages, lymphocytes, plasma cells, neutrophils, epithelioid cells, and Langhan's giant cells, and enclosed partly or completely by a thin capsule. 


\section{Mycobacterium bovis Isolation}

M.bovis was recovered from different tissue lesions by using both solid liquid media. The samples were decontaminated by using the standard protocol described by Stewart L.D. et al., (2013) and classical inoculation procedure was applied for both media.

Briefly, selected samples were homogenized, decontaminated with oxalic acid 10\% and Buffer Phosphate Saline as previously described by Markey et al., 2013. At the end the pellet was re-suspend and 0.2 $\mathrm{ml}$ were inoculated in both solid and liquid media respectively.

\section{M.bovis Isolation in Solid Media}

Although there are several laboratory techniques for diagnosis of M.bovis, isolation in solid media Lowenstein-Jensen with pyruvate still remains a very liable and widely method in use. We used LowensteinJensen with sodium pyruvate because it enhances M.bovis growth.

Briefly media was prepared by using commercial base of Lowenstein-Jensen, distillated water follow by adding sodium pyruvate. After sterilization, fresh eggs were added to the suspension in slope bottles. The proper slope bottles were used after coagulation was developed by heating at $85^{\circ} \mathrm{C}$ for 45 minutes. The inoculated media were incubated at $37^{\circ} \mathrm{C}$ and were checked every week.

\section{M.bovis Isolation in Liquid Media}

Liquid media was prepared the day of performing the decontamination of the tissues and the samples inoculation. The Bactec MGIT 960 system was used. The media content is as follow: MGIT 960 Growth-Supplement, BBL MGIT PANTA,
BBL MGIT Tube $(7 \mathrm{ml})$. The preparation steps of liquid media are: preparing PANTA solution by adding the Middlebrook OADC growth supplement to the lyophilized PANTA by mixing, in order to be dissolved properly. In every Bactec MGIT 960 tube was added $0.8 \mathrm{ml}$ from PANTA solution and than from every sample is inoculated $0.2 \mathrm{ml}$ of final solution of decontamination samples.

\section{Ziehl-Neelsen (ZN) Staining}

As part of identification procedure of M.bovis, bacterial isolates in either liquid and/or solid media were stained by ZiehlNeelsen (ZN) or Acid-Fast method described by Markey et al 2013. Briefly, the prepared microscopic smears, were floated into carbol fuchsin and heat for 10 minutes, slides were flooded into alcohol acid decolorizer for 15 minutes with several changes and finally methylene blue was added for 20 seconds.

At the end of every step slides were rinsed with tap water. Stained slides were allowed to air-dry, microscopic examination was done by using LEICA microscope and proper digital picture that show presence of M.bovis were saved.

\section{M.bovis Typing}

Isolates of M.bovis were typed by employing the spacer oligonucleotide typing (spoligotyping).

This is a valuable tools for molecular epidemiology of $M$. bovis infections and can be used to identify distinct groups of strains. The aim of typing was to characterize the strains of $M$. bovis from the calf and to compare it with other isolates either from follow up this case or within districts, country and region. 


\section{Results and Discussion}

Results of gross lesions are presented in Table 1. Typical lesions were evident in abdominal cavity, organs and lymph nodes.

\section{Isolation of M.bovis}

M.bovis was recovered from tubercular lesions of diaphragm, spleen and from lymph nodes of abdominal cavity (Table 2 ).

\section{Bacteria Identification}

Based on weekly examination we noticed Mycobacteria spp. growing at four to five weeks in liquid media and six to eight weeks on solid media. Typical colonies were grown in solid media, they are cream colored, central roughness and seems to be fragile. The culture smears prepared and stained by $\mathrm{ZN}$ method allowed us to identify presence of acid fast mycobacteria. In addition, based on spacer oligonucleotide typing, M.bovis was identified as cause of tubercular lesions detected in five-month tissue calf.

There are few reported cases of bovine tuberculosis in cattle and more rarely in calves in Albania. In addition, there is not running any program for following a typical protocol for making definitive diagnosis or following up the index case. In general, ante mortem available diagnostic test have low sensitivity. Postmortem diagnosis is based on evidence of gross lesions, histopathological changes, $\mathrm{ZN}$ staining (either direct on affected tissue, excretions, secretions and on cultures), bacterial culturing in proper media and detecting the genetic material of M.bovis. Based on presence of lesions in different tissues of the calf we identified them as typical granulomas spread in abdominal organs and visceral tissues. Despite that we didn't used any classification score system (Menin et al 2013), we conclude that tubercular formations were at different stages of development. Typical yellowish and calcified in consistency granulomas were obviously detected in spleen, which were covered with a fibrous capsule Fig $1(3,4)$ and lymph nodes, Fig.1 (1, 2). Routine examination detected only five granulomas with diameter ranged from $2-5 \mathrm{~cm}$, seen from spleen surfaces. However, detailed examination based on carefully palpation and section every $2 \mathrm{~cm}$ detected at list 17 tubercles with different diameters. During dissection of affected tissues there were present a lot of multiple intra-granulomatous areas of caseous necrosis, Fig 1(4).

Table.1 Distribution of Tubercular Lesions in Organs and Tissues of a Calf

\begin{tabular}{|c|c|c|}
\hline Distributions of granulomas & Major organs/tissue & $\begin{array}{l}\text { The calf } 5 \text { months' } \\
\text { old }\end{array}$ \\
\hline Thorax & Lung & No \\
\hline \multirow[t]{5}{*}{ Abdominal } & Liver & ++ \\
\hline & Spleen & +++ \\
\hline & Diaphragm (abdominal surface) & +++ \\
\hline & Mesentery & ++ \\
\hline & Lymph nodes & \\
\hline Thorax & Mediastinal & No \\
\hline \multirow[t]{2}{*}{ Abdominal } & Hepatic & + \\
\hline & Mesenteric & +++ \\
\hline
\end{tabular}


Table.2 Culturing Of M.bovis from Organs and Lymph Nodes of the Five-Month Calf

\begin{tabular}{|l|c|c|}
\hline \multirow{2}{*}{$\begin{array}{c}\text { Organs and lymph } \\
\text { node }\end{array}$} & \multicolumn{2}{c|}{$\begin{array}{c}\text { The time in weeks that grown M.bovis was detected according } \\
\text { media }\end{array}$} \\
\cline { 2 - 3 } & LJ Media & BACTEC-960 system \\
\hline Lung & NA & NA \\
\hline $\begin{array}{l}\text { Tubercular lesions of } \\
\text { diaphragm }\end{array}$ & 8 & 5.5 \\
\hline Spleen & 7 & 5 \\
\hline Lymph nodes & & 4 \\
\hline Hepatic & 6 & 5 \\
\hline Mesenteric & 6 & \\
\hline
\end{tabular}

Fig.1 Distribution of Tubercular Lesions (Indicated By Arrow) in a Five-Month Calf
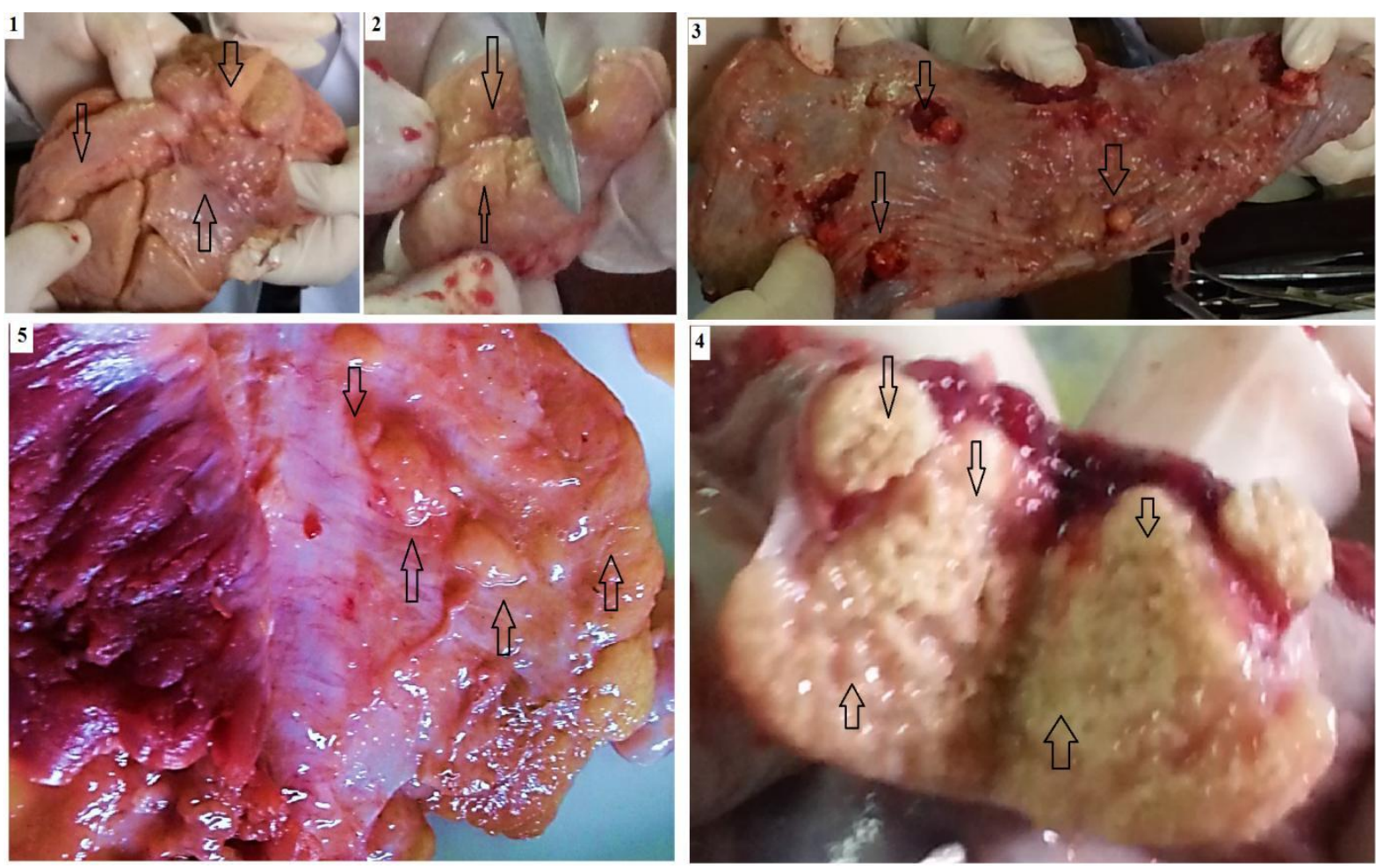

Legend. 1. Mesenterial lymph nodes. Enlargement and tubercular lesions in surface and inside lymph-nodes. 2. A lymph node dissection and typical dense tubercular lesions. 3. Encapsulated granuloma on calf spleen. 4 . Dissection of a typical tubercle in the spleen encapsulated. 5.Tubercular lesions in abdominal surface and peritoneum parietal. 
Fig.2 Histo-Pathological Analyses in Tubercular Lesions (Indicated By Arrow) in a Five-Month Calf Infected with M.bovis (40 X Magnification).

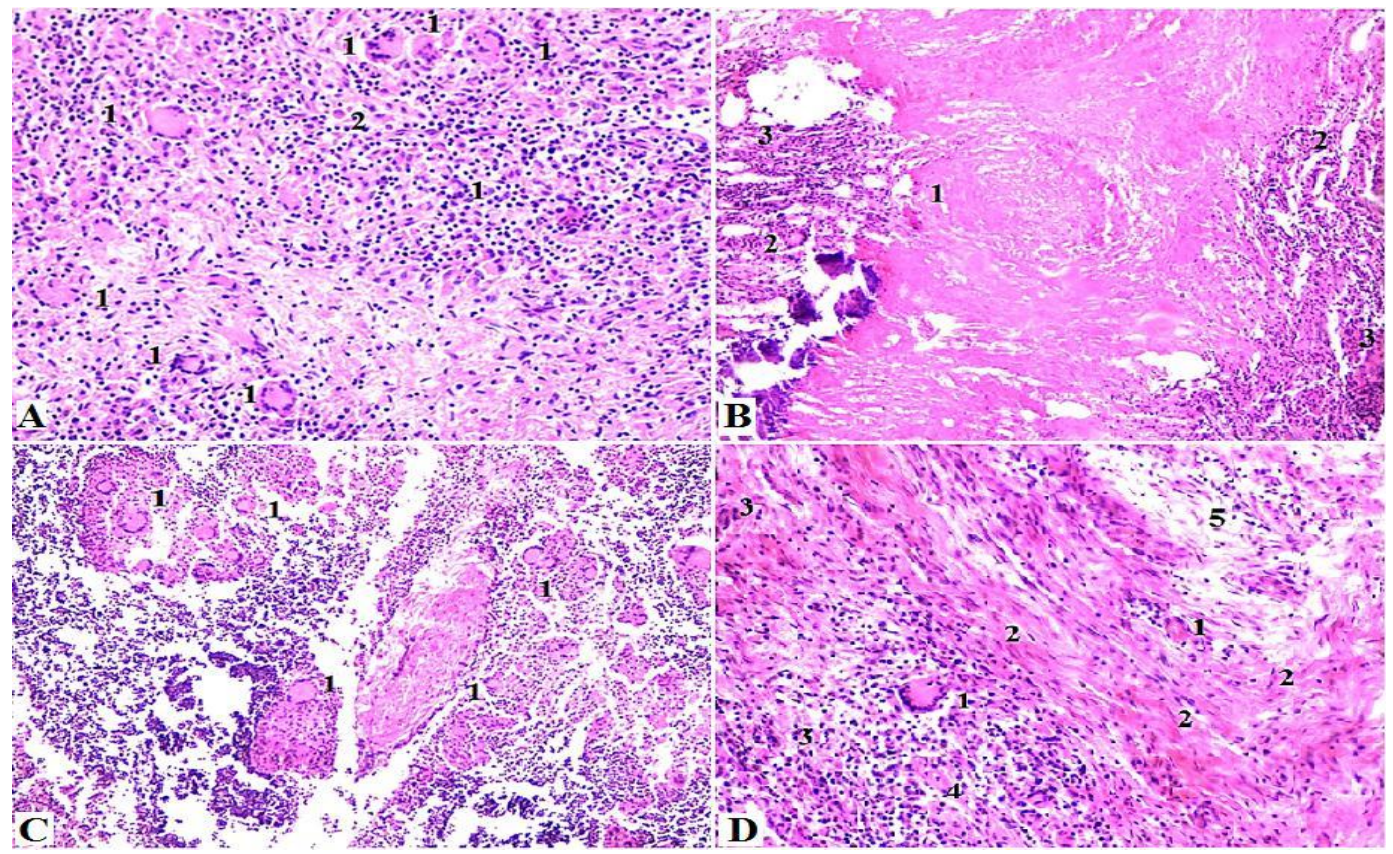

A. Microscopic slides of mesenteric lymph nodes. 1. abundant typical giant cells (fused macrophages) and 2. macrophages

B. Microscopic slides of mesenteric lymph nodes H\&E stain: 1. single granuloma with central caseous necrosis; 2 giant cell; 3 . epithelioid cells

C. Microscopic slides of spleen H\&E stain. 1. giant (Langhans) cells; 2. Fibroblasts; 3. epithelioid cells; 4. macrophages and 5. Lymphocytes

D. Microscopic slides of mesenteric lymph nodes. 1. Giant cell; 2. fibroblasts; 3. epithelioid cells; 4. macrophages; and 5. lymphocytes

Fig.3 M.bovis Isolation in Lj Solid Media (Left) and Liquid Media, Bactec System (Right)

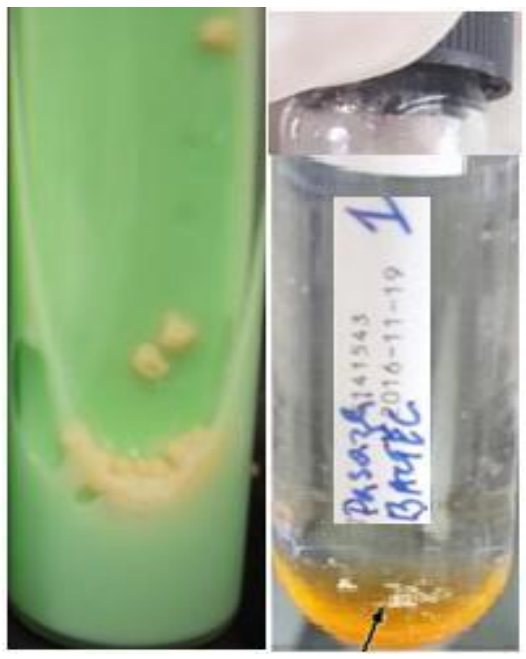


Fig.4 M.bovis Visualization Using the Ziehl-Neelsen Stain.

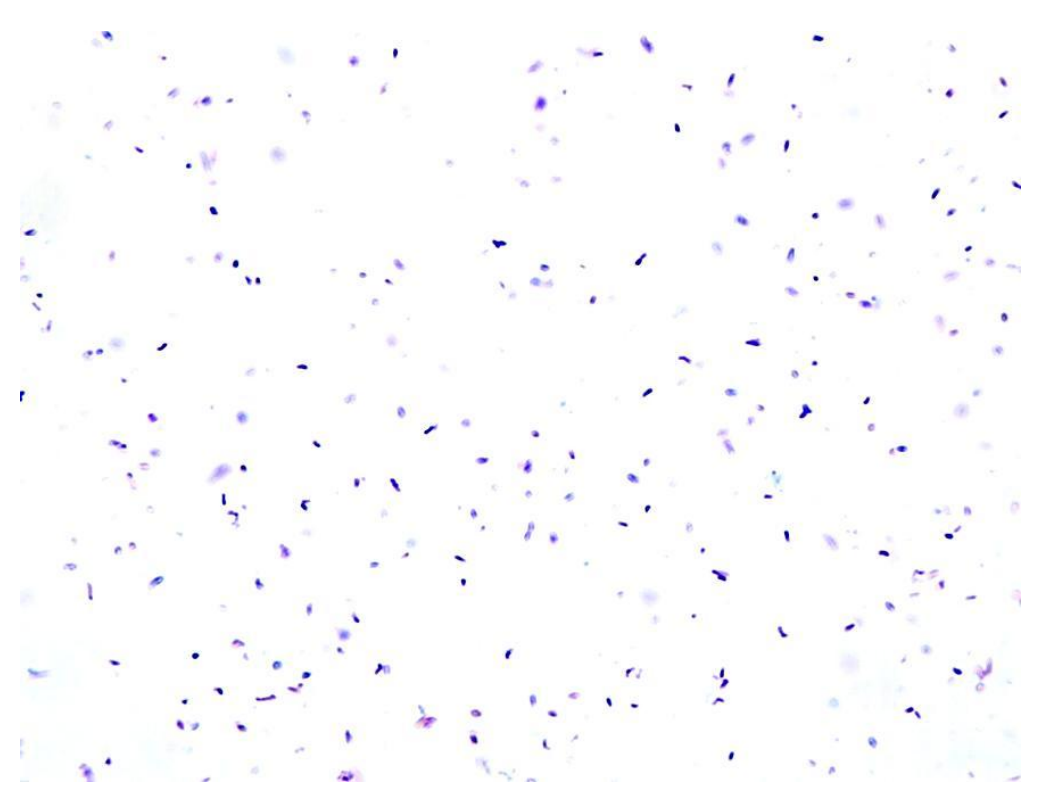

The granulomas were evident in abdominal surface of diaphragm and other abdominal visceral layers. Interestingly, there was not detected any tubercular lesion in lungs and related lymph nodes of head and respiratory system. As previously was described, the granulomas are typical lesion for bovine tuberculosis, however other pathogen may induce this condition, such as other mycobacteria and fungi, Actinomyces spp, neoplasma formations etc. All detected granulomas have a tendency to be encapsulated and appeared significant necrotic center. Norby et al., (2004) reported that sensitivity of gross necropsy method has $86.05 \%$ sensitivity. The histological examinations show involvement of typical cells and other tissue changes. In spleen and lymph nodes were identified many giant cells, macrophages, epitheloid cells, thin capsule and typical caseous necrosis. At this stage, all detected lesions were defined as highly suspected tubercular granulomas, and most likely were due by M.bovis. Isolaion of M.bovis from suspected tubercular lesions of spleen, diaphragm and mesenteric and hepatic lymph nodes confirmed bovine tuberculosis diagnosis. The typical mycobacteria colonies were grown in solid and liquid media. Mycobacteria were grown one to 3.5 weeks faster in BACTEC system compares to classical solid LJ media (Fig 3). The $\mathrm{ZN}$ stain reveals presence of acid fast bacteria in microscopic slides (Figure 4). ZN staining method may be used direct in suspected tubercular tissue lesions, however it sensitivity is highly affected by number of mycobacteria present. In cattle, the M.bovis titer is low, however in captive and wild animals $\mathrm{ZN}$ staining is suitable for animals screening. Genotyping analyses identify all four isolates as M. bovis. Recently, molecular analyses become more popular and affordable for bovine tuberculosis diagnosis. It is important to emphasize that strain typing is highly recommended for following up the source of infections either in animals and or humans.

In conclusion, a five months' calf suffered from severe bovine tuberculosis. Typical tubercular gross lesions were widespread in all abdominal organs. The granulomatous formations were identified in histopathological examination on microscopically section stained by H\&E. In 
addition, typical microscopic view and related cells were observed in tissue sections of spleen and lymph nodes. M.bovis was recovered from affected tissues by using proper media; BACTEC system was superior compare to solid media; $\mathrm{ZN}$ stain revealed acid fast bacteria and isolates were typed as M.bovis. Based on our results and epidemiological data it is most likely that source of infection is calf's mother. Further work must be done in order to identify possible infected cattle. Screening of calf's origin farm and entirely epidemiological unit and confirmation of infected animals must be the target future work.

\section{Acknowledgments}

The authors would like to thank Dr. Ruzhdi Keçi for his constructive review of the manuscript.

\section{References}

Corner, L.A. 1994. Post-mortem diagnosis of Mycobacterium bovis infection in cattle. Vet. Microbiol., 40: 53-63.

Gormley, E., Doyle, M., Fitzsimons, T., Mcgill, K., Collins, J. 2006. Diagnosis of Mycobacterium bovis infection in cattle by use of the gamma-interferon (Bovigam $®)$ ) assay. Vet. Microbiol., 112(2-4): 171-179. doi:10.1016/j.vetmic.2005.11.029 http://doi.org/10.1111/tbed.12329

Kumar, S., Prasad, T., Narayan, P., Muruganandhan, J. 2013. Granuloma with langhans giant cells: An overview. Journal of Oral and Maxillofacial Pathology, $J$ Oral Maxillofac Pathol, 17(3): 420. doi:10.4103/0973-029x.125211

Markey, B.K., Finola Leonard, Marie Archambault, Ann Culinane, Dores Maguire. 2013. Mycobacterium species in Clinical veterinary microbiology. Edimburgh: Mosby, 14: 161-176.

Menin, Á., Fleith, R., Reck, C., Marlow, M., Fernandes, P,. Pilati, C., Báfica, A. 2013. Asymptomatic Cattle Naturally Infected with Mycobacterium bovis Present Exacerbated Tissue. Pathology and Bacterial Dissemination. PLOS One, 8: e53884. Norby, B., Bartlett, P.C., Fitzgerald, S.D., Granger, L.M., Brunning-Fann, C.S., et al. 2004. The sensitivity of gross necropsy, caudal fold and comparative cervical tests for the diagnosis of bovine tuberculosis. $J$. Vet. Diagn. Invest., 16: 126-131.

Palmer, M.V., Waters, W.R., Thacker, T.C. 2007. Lesion development and immunohistochemical changes in granulomas from cattle experimentally infected with Mycobacterium bovis. Vet. Pathol., 44(6): 863-74.

Pollock, J.M., Neill, S.D. 2002. Mycobacterium bovis infection and tuberculosis in cattle. Vet. J., 163: 115-127.

Ramakrishnan, L. 2012. Revisiting the role of the granuloma in tuberculosis. Nat. Rev. Immunol., 12: 352-366.

Ramos, D.F., Tavares, L., Silva, P.E.A.D., Dellagostin, O.A. 2014. Molecular typing of Mycobacterium bovis isolates: a review. Brazilian J. Microbiol., $\quad 45(2)$ : 365-372. http://doi.org/10.1590/s151783822014005000045

Roex, N.L., Cooper, D., Helden, P.D.V., Hoal, E.G., Jolles, A.E. 2015. Disease Control in Wildlife: Evaluating a Test and Cull Programme for Bovine Tuberculosis in African Buffalo. Transboundary And Emerging Diseases, Transbound. Emerg. Dis.,

Stewart, L.D., Mcnair, J., Mccallan, L., Gordon, A., Grant, I.R. 2013. 
Improved Detection of Mycobacterium bovis Infection in Bovine Lymph Node Tissue Using Immunomagnetic Separation (IMS)Based Methods. PLoS One, 8(3). doi:10.1371/journal.pone.0058374

Vural, S.A., Alcigir, M.E. 2010. Detection of pathomorphological and immunohistochemical findings of tuberculosis in cattle slaughtered in
Ankara and its surroundings. Ankara Üniv Vet Fak Derg, 57: 253-257.

World Organisation for Animal health (OIE). 2009. "Manual of Diagnostic Tests and Vaccines for Terrestrial Animals 2009. Chapter 2.4.7: bovine tuberculosis adopted, May 2009, http: //www.oie.int/fileadmin/Home/eng/H ealth standards/tahm/2.04.07 Bovine TB.pgf.

\section{How to cite this article:}

Anita Koni, Lenida Surraj, Pëllumb Zalla, Silva Tafaj, Xhelil Koleci. 2016. A Case Study of Bovine Tuberculosis in Calf in Albania. Int.J.Curr.Microbiol.App.Sci. 5(5): 855-863. doi: http://dx.doi.org/10.20546/ijcmas.2016.505.088 